Zvonimir Stopić \& Li Yunxiao

\title{
Confusion among the Communists: Yugoslavia, China and the 1948 Resolution of the Cominform ${ }^{1}$
}

\author{
A "Wise politician" becomes a "violator of the basic principles \\ of Marxism and Leninism"
}

In June 1948, the Communist Party of Yugoslavia (CPY) was collectively denounced by other communist parties for its political and territorial aspirations on the Balkan Peninsula, as well as for the Yugoslav leader Josip Broz Tito's defiance toward Stalin, and was removed from the Cominform. ${ }^{2}$ The leadership of the Chinese Communist Party (CCP), which was at the time busy fighting against Chiang Kai-shek's reactionaries, reacted much in the same way other communist parties did. On 14 July 1948, the main newspaper of the CCP, the People's Daily, publicized the Central Committee of the CCP's "decision" which stated that in order to guard the fundaments of Marxism-Leninism, the international workers' movement, peace and democracy, and for the sake of protection of the people of Yugoslavia from American imperialism, the CCP fully agreed with the resolution compiled by the communist parties of Bulgaria, Romania, Hungary, Poland, the Soviet Union, France, Czechoslovakia and Italy. ${ }^{3}$ Explaining how the Yugoslav leadership, namely Josip Broz Tito, Edvard Kardelj, Milovan Đilas and Aleksandar Ranković, acted in violation of the basic principles of Marxism-Leninism, this decision urged all party cadres in China to "seriously study the Cominform meeting

1 This paper was completed during a bilateral project between the Chinese Capital Normal University and the Slovenian Science and Research Center Koper, entitled "China and Yugoslavia in the Global South: Convergences and Divergences".

2 Literature on this topic is abundant and the main titles in Serbian, Croatian, and English include Banac (1988); Bekić (1988); Gibianskii, Naimark (1997); Jakovina (2003); Jakovina (2002); Lees (1997), etc. In China, we can find two books on the issue: 沈志华 [Shen Zhihua] (2002); 郝承敦 [Hao Chengdun] (2007).

3 See: “中共中央委员会关于南共问题的决议” [Central Committee of CPC's Decision on the question of Yugoslavia], People's Daily, 14 July 1948. 
resolution on the problem of the Communist Party of Yugoslavia for the purpose of strengthening the class, the Party, internationalism, the spirit of self-criticism and the instilling of discipline." ${ }^{4}$

The CCP's understanding and presentation of Yugoslavia shifted dramatically when the Cominform resolution of 1948 branded Tito a traitor of Marxism. As we will see, though, denouncing Tito involved more than just stale ideological rhetoric and headlines in the press. Prior to the summer of 1948, the Chinese communist press, such as the People's Daily or the World Affairs, a journal specialized in foreign affairs, would from time to time publish news, reports or essays on Yugoslavia in which Chinese communist supporters could read about the success of Yugoslavia's anti-fascist struggle, revolution and social development, Yugoslavia's new (1945) constitution and land reform, its territorial and ethnic diversity, the problem of Trieste, trade agreements with other communist countries and other current events. ${ }^{5}$ These articles were similar in their positive tone and volume to the writings about other communist countries, parties and movements, and in them the Yugoslav leader Josip Broz Tito was often given high praise and usually titled as "Marshal" (铁托元帅). Only a month before the Cominform resolution, for example, the People's Daily was still singing high praises to Tito calling him an "excellent commander in Chief", a "wise politician", whose accomplishments are the "cornerstone of the solid friendship and unity of the federation of Yugoslavia's nationalities." The only exceptions to these favorable texts were two articles the World Affairs published in January 1948 entitled "Fireside chats on Tito" and "Issues of economic policy in Yugoslavia", which, in a way, announced the trouble Yugoslavia would soon find itself in. ${ }^{7}$ While the first one, basing its claims on the information obtained from the veiled but knowledgeable "Mr. X" (probably an "expert" coming from the Soviet Union), criticized Yugoslavia's communist leaders and Tito in particular for making mistakes in their ideological thinking and for acting against the working class, the second article, in a somewhat milder tone, warned about the overlooks that were made in the development toward communism and made suggestions for the Yugoslav government, urging it to take more control over certain capitalist elements. ${ }^{8}$

4 Full quote: “全党干部都应当认真研究共产党情报局会议关于南斯拉夫共产党问题的决议, 借以加强党 内关于阶级的、党的、国际主义的、自我批评精神和纪律性的教育”; in: Ibid.

5 See as an example: 石啸冲 [Shi Xiaochong], “新生欧洲介绍 : 南斯拉夫” [Presenting New Europe: Yugoslavia], World Affairs, 1946-I, 8 January 1946, pp. 12-15; “南斯拉夫的新宪法” [The New Constitution of Yugoslavia], World Affairs, 1946-XV, 16 April 1946, pp. 29-30; 南斯拉夫 [Yugoslavia], People’s Daily, 23 February 1947; “南斯拉夫的土地改革” [Yugoslavia’s Land Reform], People’s Daily, 25 July 1947; “苏波·苏南订贸易协 定”[Poland, Yugoslavia and the Soviet Union signed trade agreements], People's Daily, 11 August 1947.

6 Full quote: “约西普·布罗兹·铁托, 不仅只是一个出色的统帅, 而且也是一个英明的政治家, 新南斯拉 夫一一联邦人民共和国的创建人。作为这一联邦人民共和国底基石的是南斯拉夫各民族间的巩固友谊 与团结”; in: 波列威 [Bo Liwei] “铁托” [Tito], People’s Daily, 10 May 1948.

7 See: 胡以忠 [Hu Yizhong], “围炉话狄托” [Fireside chats on Tito], World Affairs, 1948(II) (15 January 1948), pp. 4-5; 梅碧华 [Mei Bihua], “南斯拉夫事件中的经济政策问题” [Issues of economic policy in Yugoslavia], World Affairs, 1948(II) (15 January 1948), pp. 6-7.

See: Ibid. 
Nevertheless, these exceptions did not soften the overall rough change in attitude all that much. As late as early June 1948, the readers of the People's Daily could still find articles that described Yugoslavia and Tito in warm sentiments. The last three were written by Liu Ningyi, a high-ranking Party functionary who visited Yugoslavia and held talks with Tito a little less than a year earlier. ${ }^{9}$ Deeply impressed by his experiences, Liu Ningyi did his best to describe the destruction suffered by Yugoslavia during the Second World War, the heroic war victories of Yugoslavia's communists, Tito's personal influence during the war and the post-war restoration, Yugoslavia's impressive economic achievements, the construction of the railroads, opposition to American imperialism, kindness and modesty of the people, strengths of the workers and the peasants. He was especially touched by the strong will of women and diligent young people who, unlike their western counterparts who climb mountains because they have food on their table and have nothing to do, are urging people to "remold the mountains and conquer the rivers." 10

\section{On the palm of imperialism: Chinese presentation of Yugoslavia after the resolution}

After the change in attitude toward Yugoslavia was made public with the Central Committee's decision and further confirmed with the proclamations of the Soviet Union and Albania that followed shortly after, as well as with additional "instructions" on how Party cadres should organize seminars and lectures to study the Cominform resolution and CCP's decision, the Chinese communist press slowly began to define the vocabulary for describing the development of Yugoslavia's socialism and Yugoslav communist leadership, which would be re-used and further refined in the years to come. ${ }^{11}$ In the very beginning, this was mostly done by following the lead of the Soviet Union's and other East European communist countries' press: reprinting articles from other

9 After his return to China, Liu Ningyi (刘宁一) published altogether three flattering articles about Yugoslavia in the People’s Daily: “铁托和新南斯拉夫” [Tito and the New Yugoslavia], 26 October 1947, “南斯拉夫通讯一一 在一个新兴的国家里”[Yugoslavia communications - in an emerging country], 20 December 1947, “新的青年 新的生活——记南斯拉夫'人民的青年铁道队”' [New Youth New Life - Yugoslavian People's Youth Railroad Team], 1 June 1948. Transcripts on Liu Ningyi's conversations with Tito in Ljubljana on 1 July 1947 are held in the Archives of Yugoslavia: "Marshal Tito receives the representatives of liberated territories of China syndicates and an All-Indian syndical congress", 7 July 1947, Ljubljana, AJ, 507 SKJ, IX 60/II-1. Details surrounding Liu Ningyi’s trip to Yugoslavia are provided by Čavoški $(2008,2011)$.

10 Full quote: “他们不羡慕那吃饱了饭无事干而爬山消遣, 他们要改造这高山, 征服这大川”; in: 刘宁一 [Liu Ningyi], “新的青年新的生活——记南斯拉夫’人民的青年铁道队” [New Youth New Life - Yugoslavian People's Youth Railroad Team], People's Daily, 1 June 1948.

11 See: “南共留苏党员抗议铁托政策” [Soviet Union CP protests over Tito's Policies], People's Daily, 30 July 1948 ; “阿共中央委员会——哌铁托集团叛卖行动” [Central Committee of Albania's CP denounced Tito's clique's traitorous actions], People's Daily, 16 July 1948; “太岳区党委指示学习关于南共决议” [Taiyue district Party committee instructs on how to study the Yugoslavian resolution], People’s Daily, 25 July 1948. 
communist controlled newspapers and journals, occasionally supplementing them with their own comments and explanations. One of the first such articles, entitled "Tito persists in playing with the mistakes of nationalism on the palm of imperialism", reprinted from Moscow's Pravda on 12 October 1948, set the basic framework for criticism China would dispense in the future. ${ }^{12}$ It blamed “Tito's clique" (铁托集团) for the deliberate isolation of Yugoslavia, prompted by the loss of its sincerest friend in international politics, and accused them of failing to understand the mechanisms of current international relations in which the brotherly organization of communist parties, the mutual friendship of new democratic countries and the friendship and cooperation with the Soviet Union are necessary conditions for building socialism, achieving freedom, democracy and safety from imperialism. ${ }^{13}$ The other article that stood out was the Cominform's report on Yugoslavia printed fully by the People's Daily on 2 December. The author of the article claimed that the weakening of the Party's role and influence over society would result in nothing but the creation of a path for Yugoslavia of becoming a colony of imperialism. Yugoslavia's leadership, full of “aristocratic arrogance” (贵族式的傲慢), was also denounced for their attempt to modify the theories of Marx, Engels, Lenin, and Stalin. ${ }^{14}$

For Chinese communists, who were fighting a full scale war against the nationalist forces of Generalissimo Chiang Kai-shek at the time and were relying on the Soviet Union's moral and material aid, there weren't many reasons to publicly question the Cominform's resolution. ${ }^{15}$ More so since the support of the United States to the Generalissimo was a clear enough indicator to the $\mathrm{CCP}$ that Chinese land was at that same moment being transformed into the very first battleground in the colossal and historic conflict between communism and imperialism. One that could even evolve into World War III because of the undeniably aggressive nature of imperialism, as Mao believed. ${ }^{16}$ After all, it was Tito's communists who deviated from the wishes and guidelines of the Soviet Union and thus endangered the unity of the international workers' movement, regardless of the reason as to why they had done that.

12 See: “铁托坚持民族主义错误被玩弄于帝国主义掌中” [Tito Persists to play with the mistakes of nationalism on the palm of imperialism], People's Daily, 12 October 1948.

13 See: ibid.

14 See: “南斯拉夫共产党的领导集团修改了马列主义关于党的学说” [Yugoslavia's Communist Party leadership clique is revising Marxism-Leninism], People's Daily, 2 December 1948.

15 The CCP's relations with Stalin during the Chinese civil war were far from simple. Questions of the level of Soviet influence in Chinese affairs, the reach of the Soviet Union's dominance in Asia and China's role in the Soviet Union's confrontation with the United States, among others, troubled the relations between Mao and Stalin from the beginning of their alliance. See: Kim Donggil (2010); 沈志华 [Shen Zhihua] (2013), chapter The CCP-CPSU High-level Contacts and the foundation of the Alliance's; and Niu Jun's chapter The Origins of the Sino-Soviet Alliance, in Westad (1998).

16 For Mao's fears see for example his report during the CCP Central Committee meeting held in Yangjiagou, Shaanxi (杨家沟, 陕西省) in December 1947, “目前形势和我们的任务” [The present situation and our tasks], in MZDCW-4. 
The reprints from the Communist Bloc press simultaneously served as public shows of loyalty to Stalin, as indirect guidelines on and reminders of the proper course of communist development, as well as public warnings against the questioning of the Party's role. Such reprints continued throughout 1949. In them, the Chinese public could read about how Hungarian communists Mátyas Rákosi and Jósef Révai saw Yugoslavia's turning towards the North Atlantic Treaty Organization (NATO) and imperialism, partly follow the exchange of letters between the Soviet Union and Yugoslavia, educate themselves on the horrible conditions Yugoslavs had to endure under Tito, learn about the fates of condemned Yugoslav communists and gain better understanding of the negative role Yugoslavia played in the Greek Civil War. ${ }^{17}$ The original Chinese articles followed the trends set by these reprints. One such article, for example, the "New situation of the new democratic countries in Southeast Europe", published in the World Affairs in January 1949, singled out Yugoslavia as the only country in Southeast Europe that was not building socialism and fighting against imperialism. ${ }^{18}$ The other, "Tito's clique and the Marshall Plan", published in the World Affairs about a month later, described Tito's communists as a traitorous clique and “the tail of imperialism” (帝国主义的尾巴) and classified its members as fake communists and agents of the United States. According to this latter article, Yugoslavia, as a “vassal of Wall Street” (华尔街的附庸), had already joined the Marshall Plan and become a supporter of NATO. ${ }^{19}$

\section{There is no third road: Mao Zedong proves he is not Tito}

The closer Mao got to achieving victory in China, the more urgent the question of how the New China would actually behave after the triumph of the communists grew. All the more because the communist world was simultaneously witnessing Yugoslavia's unyielding defiance, which only gave more reason for Stalin to deepen his already strong mistrust of Mao. As Chinese scholars Li Danhui and Shen Zhihua noted, Stalin "considered Mao a nationalist who might follow in Tito's footsteps," and Mao himself was very much aware of this..$^{20}$ Mao personally tried to shake off this "Asian Tito" stigma on

17 See: Josef Revai, “铁托集团一一西洋公约非正式的支持者” [Tito's clique - Supporter of the North Atlantic Treaty], World Affairs, 1949(VI) (12 February 1949), pp. 19-20; Duško Novakov, “南斯拉夫人民反铁托党徒 的斗争加剧了” [The struggle between Tito's gang and Yugoslavia's people is becoming more intense], World Affairs, 1949(VI) (12 February 1949),p. 21; Mátyas Rákosi, “南斯拉夫的托洛茨基分子是帝国主义的突击队” [Trotsky fraction in Yugoslavia is a commando of Imperialism], People's Daily, 3, 4, 5 August 1949; “铁托集团 和美帝一起公开支持雅典反动派” [Tito and the American imperialism openly support Athens' reactionaries], People's Daily, 21 August 1949; 铁托反革命集团的假面具撕掉了 [Tito's counterrevolutionary clique's mask torn off], People's Daily, 27 August 1949.

18 See: “东南欧新民主国家的新形势” [New situation of the new democratic countries in Southeast Europe], World Affairs, 1949(I) (8 January 1949), pp. 17-18.

19 See: “鐵托集团和马歇尔计划” [Tito's clique and the Marshall Plan], World Affairs, 1949(VI) (12 February 1949), pp. 6-7.

20 See: Li Danhui, Shen Zhihua (2011), p. 48. 
several occasions. In January and February 1949, for instance, when Anastas Mikoyan visited China in order to discuss the CCP's organization issues and the scope of the CCP's cooperation with other communist parties with Mao Zedong, Zhou Enlai, Liu Shaoqi, Zhu De and Ren Bishi, Mao showed significant interest in Tito and Yugoslavia. ${ }^{21}$ In two telegrams he sent to Stalin, Mikoyan reported that on more than one occasion, while trying to show his concern over the damage Yugoslavia might cause to the unity of the Communist Bloc, Mao clearly referred to Tito as a traitor, equating him with Mao's own Long March enemy, Zhang Guotao. ${ }^{22}$ The CCP's dependency on the help from the Soviet Union, coated by the exponentially rising global tension between socialist- and capitalist-oriented countries made Mao's position quite delicate. Realizing that attacks on Yugoslavia from the press, as well as his own attempts at distancing himself from Tito, were far from enough to reassure Stalin, Mao opted for a more grandiose show of loyalty. In June 1949, he presented the essay "On the people's democratic dictatorship" in which he enumerated three strict guidelines upon which the foreign policy of the soon-to-be established People's Republic of China would be constructed. With "Leaning to one side" (一边倒), Mao pledged that China would continue its development leaning solely to the Communist Bloc, while with the "setting up the new household" ( 另起炉灶) and the “cleaning the house before entertaining guests” (打扫干净屋子再请 客), Mao indicated that New China would discard agreements which were humiliating for China and establish diplomatic relations with other countries on an equal footing and would do this only after the influence of the imperialists was eliminated. Out of these three guidelines, the first was designed to show Mao's and CCP's undivided loyalty to the Soviet Union. ${ }^{23}$ As Mao explained, "all Chinese without exception must lean either to the side of imperialism or to the side of socialism. Sitting on the fence will not do, nor is there a third road. We oppose the Chiang Kai-shek reactionaries who lean to the side of imperialism, and we also oppose the illusions about a third road." ${ }^{24}$ In this last part it is not difficult to recognize an indirect reference to the only socialist country at that moment to have "chosen" to steer its development along a new, separate road.

21 See: "Record of the Mikoyan and MZD meeting: On Chinese communist party history", Telegram no. 16471, 3 February 1949; "Mikoyan's telegram to Stalin: Opinion on Yugoslavia", Telegram no. 34406, 4 February 1949, RAC, vol. I, p. 420.

22 Zhang Guotao (张国奉) was one of the founding members of the CCP and among the Party's most distinguished leaders until the events of the Long March when his influence diminished in favor of his rival Mao Zedong. In April 1938, he defected to Chiang Kai-shek's forces, which in communist China made his name a synonym for treachery. Before settling in Hong Kong in 1949, he fled to Taipei, and in 1968 he moved to Canada where he lived until his death in 1979. Interestingly, in 1952 in Hong Kong, Yugoslav journalist Jaša M. Levi interviewed Zhang Guotao, dubbed "the Chinese Tito". See: "From the notes of Jaša Levi on Zhang Guotao, the Chinese Tito", May 1952, AJ507 SKJ 60-I-12. Also see Zhang Guotao's (1971) memoirs.

23 See: “论人民民主专政” [On the people's democratic dictatorship], MZDSWFP, MZDCW-5. For more on Mao's three principles see: 牛军[Niu Jun] (2013); pp. 114-131; 沈志华 [Shen Zhihua] (2013), pp. 125-133; 黄 庆[Huang Qing], 王巧荣[Wang Qiaorong], 武力[Wu Li] (2016), pp. 8-22; Li Danhui, Shen Zhihua (2011); pp. 3-14; Lüthi (2008), pp. 28-31, etc.

24 See: “论人民民主专政” [On the people’s democratic dictatorship], MZDSWFP, MZDCW-5. 
Mao's "leaning to one side", or better put, "there is no third road" guideline soon became a focal point from which criticism was aimed at Yugoslavia and Tito. A couple of months after its publication, several Chinese high-ranking functionaries used it to further distance China from Yugoslavia. Guo Moruo (郭沫若), a poet, Mao’s friend and the vice-Chairman of the Preparatory Committee of the Sino-Soviet Friendship Association, stated that "Tito today is completely following the old road Chiang Kai-shek took 23 years ago. (...) Chiang Kai-shek today is Tito tomorrow." ${ }^{25}$ Referring to Mao Zedong's "leaning to one side", Mao Dun (茅盾), a revolutionary writer and the vice chairman of the National Committee for literature and art, further explained that "either pro-Soviet or pro-American' or 'leaning on both sides' in international terms means surrendering to American imperialism." ${ }^{26}$ Even Liu Ningyi, whose praiseful texts on Yugoslavia and Tito the Chinese audience could read just a little over a year ago, spoke out to show his bitter disappointment. Now it was clear to him that "since the first day he betrayed the proletariat and the anti-imperialist democratic camp, Tito has placed himself into the imperialistic reactionary camp; beyond these two camps, there is not and there cannot possibly be a third road to be walked upon." Liu also warned that "if anyone intends to take Tito's road in China, Chiang Kai-shek's fate will be awaiting him”. ${ }^{27}$

Since it was important for Mao and the CCP to publicly demonstrate to the Soviet Union and the world that Mao's binary division of the world was taken seriously throughout China, and not only at the top level, a couple of days after the article containing the quotes by the functionaries appeared, the People's Daily also published another which was to show, using the example of the city of Dalian, how in reality everyone in the area controlled by the CCP, from the university deans and trade union chiefs to factory workers and Youth League members, unanimously denounced Tito for his turn toward imperialism. ${ }^{28}$ This political narrative against Yugoslavia was wrapped up by the Shanghai Liberation Daily on 29 August with the lengthy editorial "From betrayal to national treason", reprinted by the People's Daily a couple of days later. Tito's "surrender to imperialism and betrayal of the people", as the editorial claimed, "proved comrade Mao Zedong's famous saying: neutrality is a disguise, for there is no third road" ${ }^{29}$ As

25 Full quote: “今天的铁托, 在我们看来, 完全走的是二十三年前蒋介石所走的老路。( ...) 蒋介石的今 天，就是铁托的明天”; in: “北平各界拥护苏联对南照会斥铁托反动罪行指出”第三条道路”就是法西斯道 路” [All circles in Peiping supported the Soviet Union's note on Yugoslavia denouncing Tito's reactionary crime and pointed out that the 'third way' was the fascist way], People's Daily, 28 August 1949.

26 Full quote: “在国际上说什么“既不亲苏，也不亲美”或“两边靠”，实际上都是向美帝国主义投降”; in: Ibid.

27 “铁托自从他背叛无产阶级、背叛反帝民主阵营的第一天起, 就投入了帝国主义的反动阵营，在这两 个阵营之外, 没有也不可能有第三条道路可走。在中国, 谁要是打算走铁托的道路, 那么蒋介石命运 就等待着他”; in: Ibid.

28 See: “旅大各界谴责铁托” [All the circles condemned Tito], People’s Daily, 31 August 1949.

29 Full quote: “铁托集团已经完全彻底地倒到帝国主义一边，出卖了南斯拉夫人民。(...) 这一铁的事实充 分证明了毛泽东同志的名言：“中立是伪装的，第三条道路是没有的”; in: “《上海解放日报》著论痛斥 铁托反动集团背叛人民卖国” [Shanghai Liberation Daily denounced Tito's reactionary clique's of people and country], People's Daily, 31 August 1949. 
one might have expected, the editorial ended with praises of the truths emanating from Mao's "leaning on one side" principle, as well as with the request to "fight for the consolidation of the great friendship between China and the Soviet Union, and thus safeguarding and consolidating the victory of the Chinese people's revolution." ${ }^{30}$

In order to "stress a close unity with the Soviet Union, lest Mao appear as a second Josip Broz Tito" and somewhat mask their own principles of preserving "a high measure of a self-reliance and ziligengsheng (自力更生, regeneration through one's own efforts)”, as Lüthi notices, Mao and the CCP went as far as to adjust the fundamental foreign policy of the soon-to-be most populous communist country in the world. ${ }^{31}$ However, Mao's gesture did not work as well as intended. Soon the Yugoslavs would make the situation for Mao and the CCP even more awkward. This time, directly.

\section{"We did not ask for this": Yugoslavia's recognition of China}

"The peoples of our country know that this event is of historic importance, that it is the result of magnificent victories of the Chinese people, that it means the realization of a genuinely free, truly democratic and independent China and that it represents an invaluable contribution to world peace." These were the words Vladimir Popović sent to China by telegram on 5 October 1949, congratulating the CCP on their success. ${ }^{32}$ The Chinese received the telegram on the same day as the ones from North Korea, Hungary and Czechoslovakia, but despite the kind words, the "thank you" note never arrived. ${ }^{33}$ Aware of the situation China was in, the Yugoslavs knew that the probability of establishing relations with China at such a delicate moment was quite low. More so because only four days before Mao's proclamation, on 27 September, the Soviet Union denounced the treaty of friendship with Yugoslavia, taking away almost all (and much needed) foreign aid. ${ }^{34}$ However, the Yugoslavs sent the telegram anyway. They needed to do so in order to make a clear public, if not desperate, statement that they were very much loyal to the communist cause. In a diplomatic sense, this also served as a beginning of their

30 Full quote: (...) 加强以苏联为首的各国人民的反帝国主义侵略阵线的团结，为巩固中苏伟大友谊、保 卫和巩固中国人民革命的胜利而斗争”; in: Ibid.

31 See: Lüthi (2008), p. 30.

32 See: "Vlada FNRJ priznalaNarodnu vladu Narodne Republike Kine" [The government of the FPRY recognized the Government of the People's Republic of China], Borba, 6 October 1949.

33 China received the telegram of recognition on 6 October 1949. See: DDDAECDR (2006), p. 571.

34 The act of the Soviet Union was followed shortly after by all the other countries of the Communist Bloc. Information on the chronology of the events, the full texts of Soviet bloc countries' treaty cancellations, as well as Yugoslavia's responses can be found in Bela knjiga [White Book] (1951), published by the Yugoslavian Foreign Affairs Ministry as part of preparations for their initiative to condemn the Soviet Union and other Soviet Bloc countries' hostile activities toward Yugoslavia in the United Nations. Also see: "Otkazivanje ugovora o prijateljstvu s Jugoslavijom - Akt uperen protiv interesa mira i međunarodne suradnje"[The cancellation of the friendship treaty with Yugoslavia - an act aimed against the interests of peace and international cooperation], Borba, 9 October 1949. 
building of leverage in their diplomatic dialogue with the Soviet Union, China and the rest of the Communist Bloc. ${ }^{35}$

For the Chinese, Yugoslavia's recognition came somewhat unexpectedly and instantly drew a new shadow over the greatest day of the CCP. Ten days after the recognition came, Mao met with Nicolai Vasilyevich Roshchin, the first Soviet Union ambassador to China, to explain that China did not ask Yugoslavia for the recognition and to assure him that the $\mathrm{CCP}$ will not respond or do anything concerning Yugoslavia without prior consultations with Moscow. ${ }^{36}$ The Chinese press also made a stand, with three articles denouncing the CPY and Tito in the People's Daily. ${ }^{37}$ The last one, entitled "Imperialists' lead running dog, Tito, is changing Yugoslavia into a fascist prison for Wall Street", marking the end of the year, accused Tito of implementing shameless policies of trading important resources in exchange for capital from the imperialists and his ruthless exploitation of Yugoslav workers. ${ }^{38}$

However, Chinese diplomatic unresponsiveness, as well as the fact that the attitude of the $\mathrm{CCP}$ and the Chinese press toward Yugoslavia did not differ at all from those of other Communist Bloc countries, troubled the Yugoslavs very little. They simply ignored the Chinese press and diplomatic hints and decided to use China and the victories of the $\mathrm{CCP}$ to prove their socialist allegiance. Even after 6 October, the Yugoslav daily Borba regularly continued to publish articles which supported the struggle of Chinese communists against Chiang Kai-shek's troops as if nothing had changed, ${ }^{39}$ while Yugoslav diplomats assumed the role of loud defenders of the Government of the People's Republic's right to represent China in the UN. The issue of Chinese representation in the UN was of special value for the Yugoslavs because in discussions about it they could present themselves as

35 Although it was not possible to notice this at that time, the Chinese non-responsiveness regarding the recognition would in the future inadvertently help Yugoslav diplomats to construct a myth of their righteousness and uncompromising positions in relation to "important issues". A valuable counterpoint to this myth is given by Jovan Čavoški who noted that Yugoslavia was, as far as it was known, actually the only communist country besides the Soviet Union that gave its support for the nationalist government of Chiang Kai-shek. See: Čavoški (2011), pp. 562-565.

36 See: "Record of Mao Zedong and Roshchin talks", Document No. 09925, RAC, 16 October 1949, vol. I, pp. 130-131.

37 See: “铁托叛徒出卖战略富源” [Traitor Tito sold strategic resources], “铁托匪帮作希保皇军帮凶” [Tito’s gang is an accomplice of Greek imperial army], and “南国人民不顾叛徒迫害” [Yugoslavian people in defiance toward traitorous persecution], People's Daily, 15 and 16 October 1949.

38 See: “帝国主义头号走狗铁托把南国变成法西斯牢狱出卖整个国家给华尔街” [Imperialists' leading running dog Tito is changing Yugoslavia into the fascist prison for Wall Street], People's Daily, 30 December 1949.

39 An average reader from Yugoslavia was up to date with the successes of the People's Liberation Army and the course of events that took place in China. As examples see "Jedinice Narodnooslobodilačke armije oslobodile otok Kintang" [Units of the People's Liberation Army liberated the island of Jintang], Borba, 10 October 1949; "Narodnooslobodilačka armija oslobodila Liučou u centralnom Kvangsiu i nekoliko oblasnih gradova" [The people's Liberation Army liberated Luizhou in Central Guangxi and several cities in the district], Borba, 28 November 1949; "Privode se kraju velike operacije za okruživanja koumintaških trupa na frontu južne Kine” [Large operations of surrounding the Kuomintang troops on the South China front are coming to an end], Borba, 10 December 1949; "Kuomintaška vlada pobjegla na Formozu" [Kuomintang Government escaped to Formoza], Borba, 10 December 1949; "Oslobođen je Hainan" [Hainan is liberated], Borba, 4 May 1950; etc. 
firm supporters of socialism and at the same time distance themselves from the aggressive policies of the Soviet Union. In various UN committees and the UN Security Council, where, on 20 October, the United States conveniently helped them find a place, ${ }^{40}$ Yugoslav diplomats would hold their ground in defending the cause of the CCP by refusing to discuss issues of global importance because a proper representative of China was not present and thus annoying the representatives of the US with whom they had begun to negotiate the conditions of foreign aid, but would never go as far as to boycott any of the committees in which Kuomintang representative sat, as the representatives of the Soviet Union and other Communist Bloc countries did. ${ }^{41}$ In addition, when it came to the relations between China and the Soviet Union, the Yugoslavs held nothing back. Ten days after the signing of the Sino-Soviet Treaty of Friendship, Alliance and Mutual Assistance, for example, Borba published a lengthy article in which the main focus was on the Soviet Union's hindrance of the CCP's struggles during the Second World War, Stalin's post-war alliance with Chiang Kai-shek, and Stalin's unprincipled political shrewdness which would surely hurt China in the long run. ${ }^{42}$

The Yugoslavs, who at the time needed all the photons of the international limelight they could get, in reality showed little concern over how much their support was actually helping the $\mathrm{CCP}$ or Mao. Although from the available documents and the press sources we can sense that some genuine brotherly sentiments over the development of communism in China did exit, Yugoslavia's "principled" positions on the victories of the CCP in China, the Chinese representation in the UN or Stalin's insidious manipulations of China in reality served mainly to prove that, despite the criticisms from the Communist Bloc, Yugoslavia had never abandoned socialism, and to emphasize the danger coming from Stalin and the Soviet Union. Chinese communists were of course quite aware of what Yugoslavia was doing in China's name. Although the Chinese were quite reserved when it came to Yugoslavia for the better part of 1950, printing only a few news reports per month, Yugoslavia's persistent referring to China continued to heat up the ever present question of whether China and Mao would in fact become the Asian Yugoslavia and Tito.

40 Yugoslavia participated in the proceedings of the Security Council from 1 January 1950 until 31 December 1951. See: Jovanović (1985), pp. 27-28, 85-89.

41 In a heated debate at the beginning of the United Nations Security Council Social Committee session over the presence of a Kuomintang representative, for example, Yugoslav delegate Gustav Vlahov voted the same way as the Soviet Union and Poland did. In another event, during a session of a UN Security Council Committee for Conventional Armament, Yugoslav Delegate Đuro Ninčić, together with the Soviet Union and delegates from India, voted for the eviction of the Kuomintang representative, but did not leave the session, as Soviet delegate Yakov Malik did. See: "Jugoslavenski delegate na zasjedanju socijalne komisije zahtjeva pravilno rješenje pitanja predstavništva Kine u OUN"[Yugoslavian representative at the Social Committee session requests the proper solution of the Chinese representation question in the United Nations], Borba, 5 April 1950; "Jugoslavenski delegat se izjasnio protiv toga da komisija nastavi rad sve dok se ne riješi pitanje predstavništva Kine" [Yugoslavian representative spoke against the continuation of the committee's procedings until the Chinese representation question is not solved], Borba, 29 April 1950.

42 See: "Povodom potpisivanja Sovjetsko-kineskog ugovora" [On the signing of the Sino-Soviet agreement], Borba, 11 February 1950. 


\section{Conclusions: the road to Korea and to the dissolution of the international communist movement}

The Cominform resolution had a tremendous impact on the CCP and Mao Zedong personally. Because of it, as we have shown, China had to adjust its general foreign policy guidelines while Mao Zedong had to justify himself before Stalin constantly. However, the impact did not stop there. Xia Yafeng noted that the events surrounding Yugoslavia also had a significant impact on the development of the policy of the United States toward China. Comparing China with Yugoslavia, the Truman administration concluded that the "victory for Communists in China would pose no overwhelming threat to American interests" mostly because, similar as it was with Tito and Stalin, "Mao Zedong and his colleagues were unlikely to defer blindly to Moscow's wishes." ${ }^{43}$ Furthermore, Truman's decision not to intervene militarily in any way on behalf of Chiang Kai-shek was guided precisely by these premises of the "CCP's Titoist tendency". ${ }^{4}$

In short, soon after the Cominform resolution, everyone made the connection between Mao and Tito. Even the Yugoslavs sensed the connection, hoping that at some level China would show that it would rather walk the path without Stalin holding its reins. To their great disappointment, not only did this not happen, but, hoping to remove the "Asian Tito" stigma, Mao Zedong took China in the opposite direction. Apart from other concerns over security and ideology that Mao had, the invasion of Korea considerably helped him win the confidence of the Soviets and remove the suspicion of him being the next Tito. As Li Danhui and Shen Zhihua remind us, in July 1958, Mao explained to the Soviet ambassador to China Pavel Iudin that he knew very well Stalin doubted that the Chinese Communists were genuine Marxists, and that "until the Korean War broke out, he did not change his opinion." ${ }^{45}$

Although the Korean War overshadowed this unpleasant episode in the international communist movement and made the connection between Mao and Tito far less tangible, the feeling of uneasiness tied to Yugoslavia lingered on around Tiananmen. Not so much because of the similarities that were once drawn between China and Yugoslavia, but because the Chinese in reality did truly believe that it was the Yugoslavs who made an error and thus betrayed the Bloc. Owing to Khrushchev's mediation in late 1954, the Chinese did soften their views on Yugoslavia, but the trust was never fully regained. It did not take long for the peace to be shattered again. First it was Tito's unwillingness to give full support to Soviet tanks during the Hungarian revolution, then Yugoslavia's refusal to sign the joint declaration of 64 communist parties in Moscow in November 1957, and finally the draft of Yugoslavia's new constitution presented at the $7^{\text {th }}$ Congress

43 See: Xia Yafeng (2006), pp. 14-15.

44 See: Xia Yafeng (2006), p. 38.

45 See: Li Danhui, Shen Zhihua (2011), p. 48. Mao Zedong quote is taken from MZDSWFP, p. 326. 
of the League of Communists of Yugoslavia in Ljubljana in April 1958. All this revealed that the intuition of Mao and the $\mathrm{CCP}$, as well as the sharp tone of past criticism, was correct all along. In the early summer of 1958, almost exactly ten years after the Cominform resolution, China, this time leading the charge, began denouncing Yugoslavia and Tito once more for their sins against Lenin and Marx. With these denouncements, which would last for the next ten years, Mao finally managed to shake off any connections he might once have had with Tito, ideologically speaking, at least. As it turned out, China's denouncements of Yugoslavia and Mao's personal liberation of the "Asian Tito" sigma ended up serving as an overture to a major Cold War event, the Sino-Soviet split and thus, peculiarly and even somewhat contradictory, made Mao's actions seemingly similar to Tito's all those years earlier. Although he did begin steering China in the opposite direction from the one Tito took, in the end Mao did exactly what Tito had done and what Stalin feared the most. He took China away from the Soviet Union.

\section{Sources and literature}

\section{Archival sources}

Arhiv Jugoslavije (AJ) [The Archives of Yugoslavia]: Savez komunista Jugoslavije (SKJ, 507) [League of Communists of Yugoslavia] - Komisija za međunarodne odnose i veze [Commission for International Relations and Liaisons]: Communist Party of China.

Bela knjiga o agresivnim postupcima vlada SSSR, Poljske, Čehoslovačke, Mađarske, Rumunije, Bugarske i Albanije prema Jugoslaviji. [The White Book about the aggressive acts of governments of USSR, Poland, Czechoslovakia, Hungary, Romania, Bulgaria and Albania toward Yugoslavia]. Belgrade, Yugoslavia: MIP FNRJ, 1951.

《毛泽东外交文选》[Mao Zedong's Selected Works on Foreign Policy; MZDSWFP] 中央文献出 版社;世界知识出版社 1994 年

《毛泽东文集》[Collected Works of Mao Zedong; MZDCW]8 卷，人民出版社 2009 年 沈志华 [Shen Zhihua]: 《俄罗斯解密档案选编：中苏关系》[Russian archives collection: On Sino-Soviet relations; RAC] (12 册) 中国出版集团，东方出版中心 2014 年

《解密外交文献-中华人民共和国建交档案》 [Declassified Diplomatic Documents - Archives of the Establishment of China's Diplomatic Relations; DDDAECDR] 中华人民共和 国外交部档案馆，人民画报社，中国画报出版社 (编) 2006 年

\section{Newspapers}

Borba

People's Daily

人民日报 [Renmin Ribao]

World Affairs

世界知识 [Shijie Zhishi] 


\section{Books}

Banac, Ivo, With Stalin against Tito: Conformist Split in Yugoslav Communism. Cornell University Press, 1988.

Bekić, Darko, Jugoslavija u Hladnom ratu 1949-55. [Jugoslavia in the Cold War, 1949-55]. Zagreb: Globus, 1988.

Gibianskii, Leonid and Norman Naimark, The Establishment of the Communist Regimes in Eastern Europe, 1944-49. Westview Press, 1997.

Jakovina, Tvrtko, Socializam na američkoj p̌senici, 1948-63. [Socialism on the American Wheat, 1948-63]. Zagreb: Matica hrvatska, 2002.

Jakovina, Tvrtko, Americki komunisticki saveznik, 1945-55. [American Communist Ally, 194555]. Zagreb: Profil International, 2003.

Jovanović, J., Jugoslavija u Organizaciji ujedinjenih nacija 1945-1953. [Yugoslavia in the United Nations, 1945-1953]. Belgrade: Institut za savremenu istoriju, 1985.

Lüthi, L., The Sino-Soviet Split. New Jersey: Princeton University Press, 2008.

Lees, Lorraine M., Keeping Tito Afloat: The United States, Yugoslavia, and the Cold War. Penn State Press, 1997.

Li, Danhui, Shen, Zhihua, After Leaning to One Side. Stanford: Stanford University Press, 2011.

Westad, O. A. (ed.), Brothers in Arms: The Rise and Fall of the Sino-Soviet Alliance, 1945- 1963. Stanford: Stanford University Press, 1998.

Xia, Yafen, Negotiating with the Enemy: U.S.-China Talks during the Cold War, 1949-1972. Bloomington: Indiana University Press, 2006.

Zhang, Guotao, The Rise of the Chinese Communist Party: The Autobiography of Chang Kuo-tao. Kansas: University Press of Kansas, 1971.

牛军 [Niu Jun]: 《冷战与新中国外交的缘起 (1949-1955)》 [The Cold War and the Origin of Diplomacy of PR China, 1949-1955] 社会科学文献出版社 2013 年

黄庆 [Huang Qing], 王巧荣[Wang Qiaorong], 武力 [Wu Li]: 《中华人民共和国外交史 1949-2012》[The Diplomatic History of People's Republic of China, 1949-2012] 当代 中国出版社 2016 年

沈志华 [Shen Zhihua]: 《斯大林与铁托 : 苏南冲突的起因及其结果》 [Stalin and Tito: Causes and Results of the Soviet-Yugoslav conflict] 广西师范大学出版社2002年.

沈志华[Shen Zhihua]: 《无奈的选择:冷战与中苏同盟的命运 (1945-1959)》[The Cold War and the Fate of Sino-Soviet Alliance, 1945-1959] 社会科学文献出版社 2013 年.

郝承敦 [HaoChengdun]: 《苏南冲突与东方阵营内部关系的演变》[Soviet-Yugoslavia Split and the Evolution of the Relations in the Eastern Bloc] 学林出版社2007年.

\section{Articles}

Čavoški, J., Overstepping the Balkan boundaries: The Lesser Known History of Yugoslavia's Early Relations with Asian Countries (New Evidence form Yugoslav/Serbian Archives). Cold War History, 11(4), 2011, pp. 557-577.

Kim, Donggil, Stalin and the Chinese Civil War. Cold War History, 10(2), 2010, pp. 185-202.

约万.查沃什基 [Jovan Čavoški] 《失去的联系 - 1947年中南之间一段不为人知的互动历 史》[The lost connection: an unknown history of interaction between China and Yugoslavia in 1947]《冷战国际研究史》2008年第2期. 


\section{Summary \\ Zvonimir Stopić \& Li Yunxiao \\ Confusion among the Communists: Yugoslavia, China and the 1948 Resolution of the Cominform}

Yugoslavia's expulsion from the Cominform instantly affected both the internal dynamics of the world's communist forces, as well as the sustainability of the united international struggle against the forces of capitalism and imperialism. These events created an unexpected nuisance for Chinese communists who were at the time in the midst of a relentless struggle against their ideological and political enemy, Chiang Kai-shek's Guomintang. While being in dire need of military and overall logistic aid from their communist brother, the Soviet Union, the Cominform's resolution cast a long shadow over the Chinese Communist Party, and especially its paramount leader Mao Zedong. Considering the troublesome past between the Soviet Union and the CCP and the sheer size and global strategic importance of China, a question arose in Stalin's mind: could Mao be, or rather how long it would take him to become the "Asian Tito". Using the framework set by the leading experts on Chinese Cold War relations, such as Odd Arne Westad, Shen Zhihua, Lorenz Lüthi, Xia Yafeng and others, as well as Yugoslavian and Chinese press and available archival sources, this paper will map the pace of Chinese reactions to the developments of Yugoslavia's tribulations, and will try to show the extent of the affect Yugoslavia's expulsion form the Communist Bloc had on China.

Zvonimir Stopić, Ph.D., Department of World history,

Li Yunxiao, M.A., Ph.D. candidate, Department of World history

School of History, Capital Normal University, Beijing 